Selected Papers from the 9th Radiocarbon \& Archaeology Symposium, Athens, GA, USA, 20-24 May 2019 (C) 2020 by the Arizona Board of Regents on behalf of the University of Arizona. This is an Open Access article, distributed under the terms of the Creative Commons Attribution licence (http://creativecommons. org/licenses/by/4.0/), which permits unrestricted re-use, distribution, and reproduction in any medium, provided the original work is properly cited.

\title{
BRIDGING THE GAP EBIII-IBA: EARLY INTERMEDIATE BRONZE RADIOCARBON DATES FROM KHIRBAT EL-'ALYA NORTHEAST, ISRAEL
}

\author{
Ron Lev ${ }^{1}$ - Omer Shalev ${ }^{2} \cdot$ Johanna Regev $^{1} \cdot$ Yitzhak Paz $^{2} \cdot$ Elisabetta Boaretto $^{1 *}$ \\ ${ }^{1}$ D-REAMS Radiocarbon Laboratory, Scientific Archaeology Unit, Weizmann Institute of Science, Rehovot, Israel \\ ${ }^{2}$ Israel Antiquities Authority, P.O.B. 586, Jerusalem, Israel
}

\begin{abstract}
Recent radiocarbon $\left({ }^{14} \mathrm{C}\right)$ research demonstrates that the urban culture of Early-Bronze III in the southern Levant ends around $2500 \mathrm{BC}$, and not around $2300 \mathrm{BC}$ as was widely assumed. This should extend the Intermediate Bronze Age by 200 years. Charred olive pits from Intermediate Bronze Age contexts in the site of Khirbat el-'Alya Northeast in the Judean Shephelah region (Israel) were ${ }^{14} \mathrm{C}$ dated, resulting in calibrated dates around $2500 \mathrm{BC}$. The date range of Khirbat el-'Alya Northeast samples is an indication that in the Mediterranean parts of the southern Levant, the Intermediate Bronze Age material culture appeared around the time of the decline of the preceding culture of Early-Bronze III-around $2500 \mathrm{BC}$ or somewhat earlier. Possible Intermediate Bronze settlement pattern and the site's relation to the nearby Early-Bronze city of Tel Yarmuth are discussed based on previous Intermediate Bronze and Early-Bronze related research in the surrounding area.
\end{abstract}

KEYWORDS: EB-III, Khirbat el-‘Alya, Intermediate Bronze Age, Phytoliths, Tel Yarmuth.

\section{INTRODUCTION}

Much progress was made during the last decade in archaeological research of the Intermediate Bronze Age (IBA hereafter, but also known as EB-IV) culture that existed in the southern Levant in the second half of the third millennium (e.g. D'Andrea 2014; Dever 2014; Falconer and Fall 2019). Yet it is still an enigmatic period in some aspects e.g. what was the trigger/cause for the sharp cultural change from the EB-III to the IBA that is evident in site formation processes, burial practices, and material culture? Common characteristics of this period are unfortified rural settlements, usually with only one main layer of occupation, although there are few sites with robust and stratified IBA occupation and few enclosed by walls (Richard 2010; Bar et al. 2013; Falconer and Fall 2016; Fraser 2017), a distinct pottery repertoire, abundance of vast burial grounds and copper/bronze weapons and tools.

The IBA distinct material culture was identified early in the 20th century and hundreds of IBA sites were found and excavated since then in the southern Levant. Yet there are still uncertainties regarding fundamental aspects of this period, including the IBA absolute timeframe, and possible sub-phases (D’Andrea 2012; Kennedy 2016).

Extensive research on ${ }^{14} \mathrm{C}$ dates from Early Bronze III (EB-III) urban centers in the southern Levant was conducted in recent years (Regev et al. 2012b, 2014; Höflmayer et al. 2014). This research demonstrated that the absolute dating for the end of the EB-III urban culture is around $2500 \mathrm{BC}$ and not around $2300 \mathrm{BC}$, as was widely assumed for the end of the EB-III and the start of the following period IBA (Mazar 1990; de Miroschedji 2009). The traditional dating of the boundary between EB-III and IBA to around $2300 \mathrm{BC}$ was recently advocated by Nigro (Nigro et al. 2019) based on modeling radiocarbon $\left({ }^{14} \mathrm{C}\right)$ dates from Jericho, where both those periods were excavated. If the previous EB-III urban culture indeed declined around $2500 \mathrm{BC}$, we should expect no cultural vacuum, and hence expect to find IBA absolute dates close to $2500 \mathrm{BC}$. In Transjordan, a sequence of ${ }^{14} \mathrm{C}$ dates from the site of

\footnotetext{
*Corresponding author. Email: Elisabetta.Boaretto@weizmann.ac.il
} 


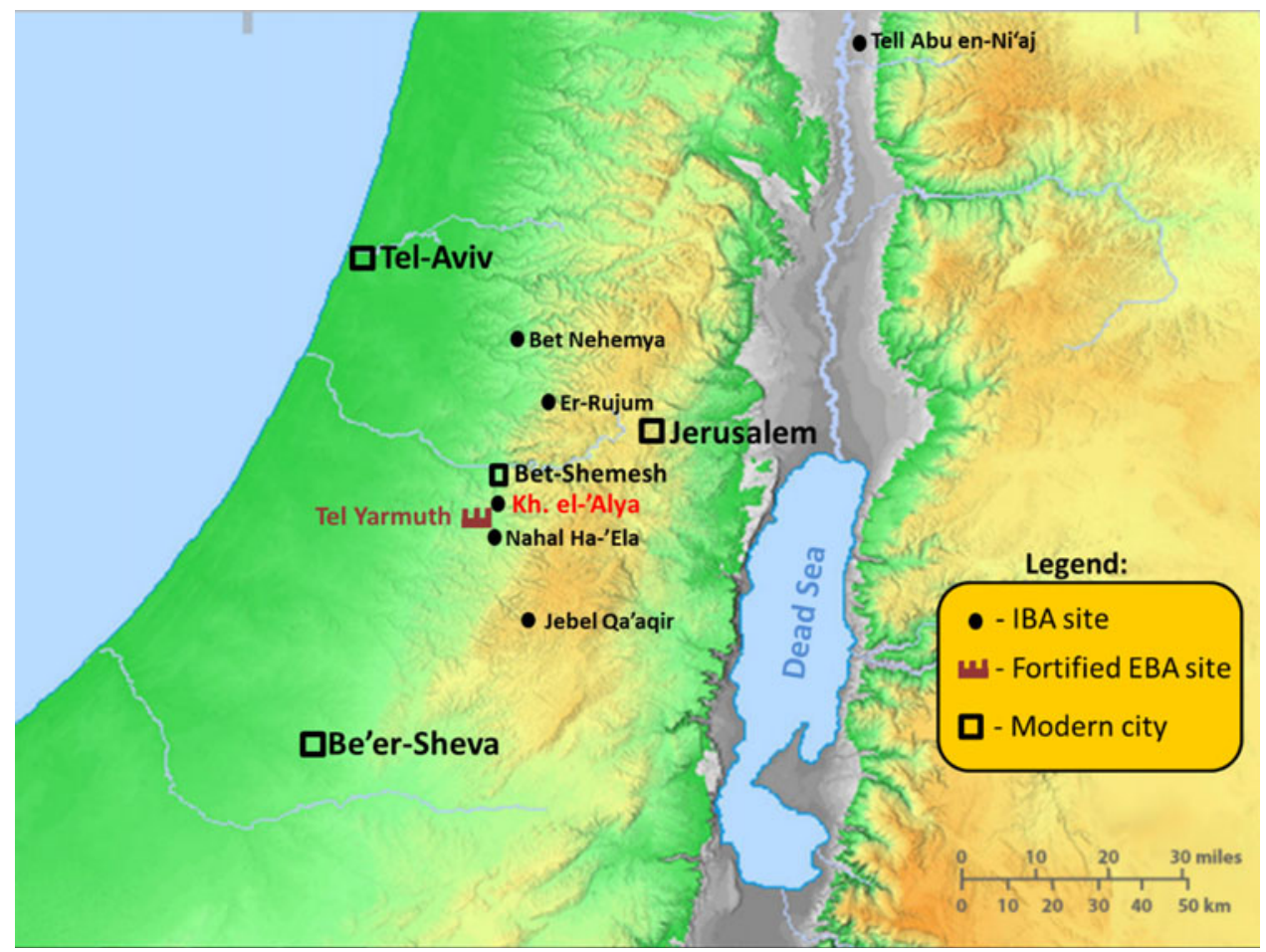

Figure 1 General map showing the location of EBA and IBA sites mentioned in this article. Modern cities are shown for reference.

Tell Abu en-Ni'aj (Figure 1) shows the IBA occupation in this site started as early as 2500 BC or slightly before (Falconer and Fall 2016, 2019). In the Mediterranean parts of the southern Levant, west of the Jordan river, short-lived samples from Ein-Ziq in the Israel Negev were recently dated $(1 \sigma)$ to $2455-2290$ BC (Dunseth et al. 2017), but no early dates from around 2500 $\mathrm{BC}$ from secure IBA contexts were published. IBA ${ }^{14} \mathrm{C}$ dates around $2500 \mathrm{BC}$ and even earlier were published from the site of Be'er-Resisim in the Negev (Segal and Carmi 2004: 145), but those dates were obtained from ostrich egg shells, and it has been demonstrated that dating of ostrich egg shell carbonate results in dates up to several centuries older than charcoal dates from the same context (Vogel et al. 2001).

\section{KHIRBAT EL-'ALYA NORTHEAST-THE ARCHAEOLOGICAL BACKGROUND}

Khirbat el-'Alya, is a small mound (ca. 5 hectares) situated in Israel's Judean Shephelah geographical region, at the southern perimeter of the modern city of Bet-Shemesh, and some $1.3 \mathrm{~km}$ northeast of Tel Yarmuth (Figure 1). Due to planned road construction, a salvage excavation was conducted by the Israel Antiquities Authority directed by Omer Shalev, at the foot of Khirbat el-'Alya (Shalev and Dallashah 2017). Area D is located in a small gulley that flows into Nahal Yimla, northeast of the mound of Khirbat el-'Alya (henceforth KANE). Three strata were recognized: remains of a small settlement dated to the IBA were labeled Stratum III; a segment of a road, dated to the Iron Age IIB, was labeled Stratum II; top level of field walls, as well as other agricultural installations, were labeled Stratum I. The latter stratum cannot be dated with certainty to any period. The state of 


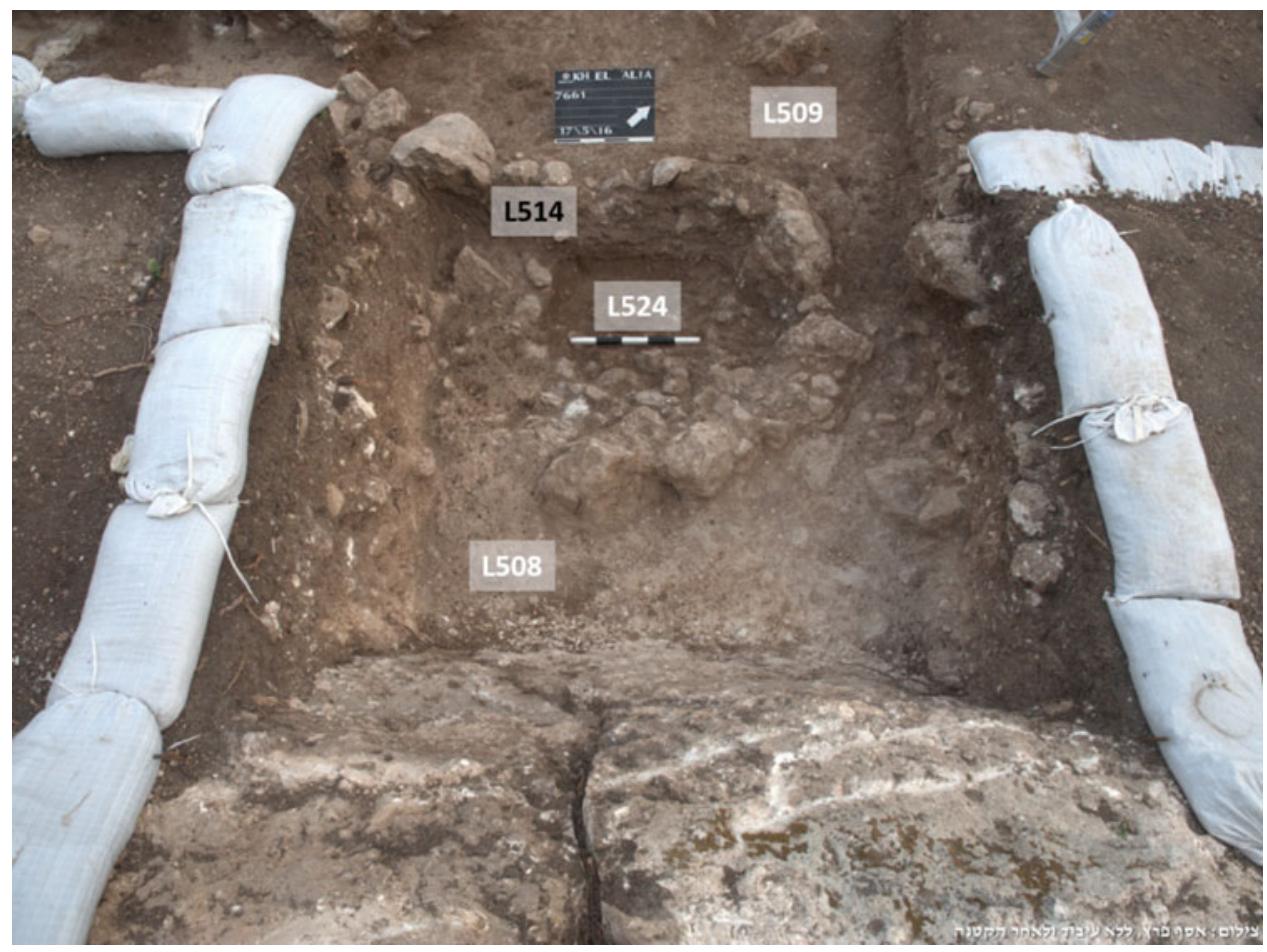

Figure 2 Oval stone installation L514/L524 (black labels—installations, white labels_earthen loci) (photo: Assaf Peretz).

preservation of the architectural remains of Stratum III was not sufficient to reconstruct a full and accurate plan, but at least two and perhaps three structures could be recognized. At the eastern part of the site, an oval installation was found (L514; ca. $1.2 \times 0.9 \mathrm{~m}$ ). The installation was erected in a pit (ca. $0.6 \mathrm{~m}$ deep) dug into the natural soil, and then lined with small un-hewed stones (Figure 2). Similar installations were found in other IBA sites, e.g. Tel Zivda (Yannai 2014: fig. 8), and Khirbat er-Ras (Feig 2016). Crushed pottery vessels, as well as hammerstone and charred seeds and pits, were found in situ inside the installation (L524; Figure 4).

The pottery found in KANE could be securely identified as representing the IBA period, except for few later sherds, mainly from the Iron-Age, that were found in the upper layers associated with a possible road section and agricultural features. Pottery vessels found within L514/L524 oval installation were all from the IBA and include:

- One large bowl made of pale pink clay with a flat cut rim (Figure 3:1);

- Three holemouths, one plain, with a more rounded rim (Figure 3:2), one with a square rim and a gentle rope-like decoration (Figure 3:3) and a spouted holemouth with a square rim and fishbone incised decoration (Figure 3:4);

- $\quad$ Four storage jars with simple flaring rim and flat base (Figure 3:5-9);

- Ledge-handles, belonging to the semi-folded type (Figure 3:10-11).

Overall, this assemblage can be ascribed to the IBA "Southern Family" (Amiran 1970; Dever 1980). Similar vessels can be found in other IBA residential sites in the Judean Shephelah area 


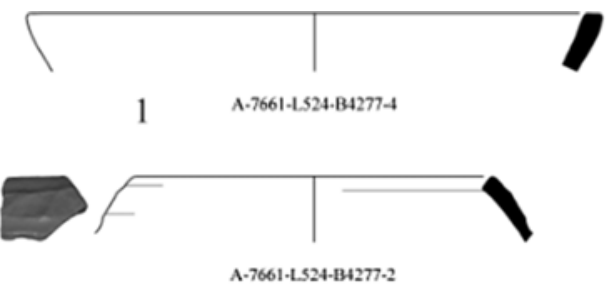

3

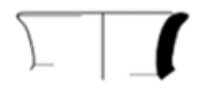

A.7661-L.524-B4277.12

5

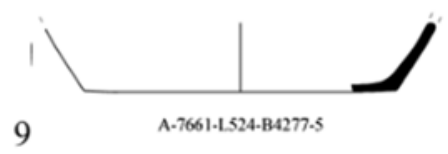

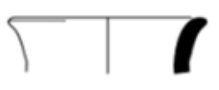

A.7661-1.524-B.3277.11
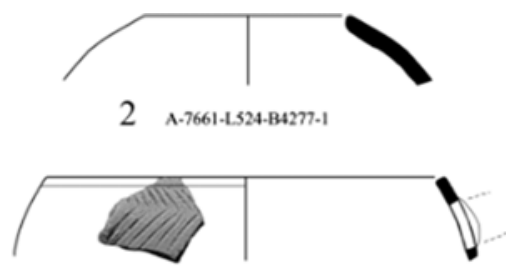

$4^{\text {A-7661-L.524-B4277-02 }}$

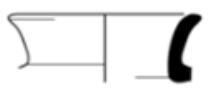

A.7661-L.524-B4277.10

7

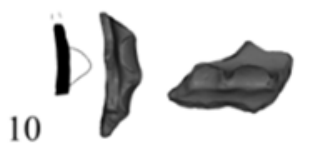

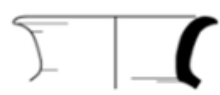

A-7661-L.524-B4283-1

8

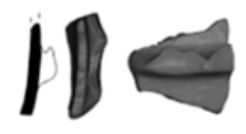

nan

0

$10 \mathrm{~cm}$

Figure 3 Pottery vessels found in the oval installation (L524).

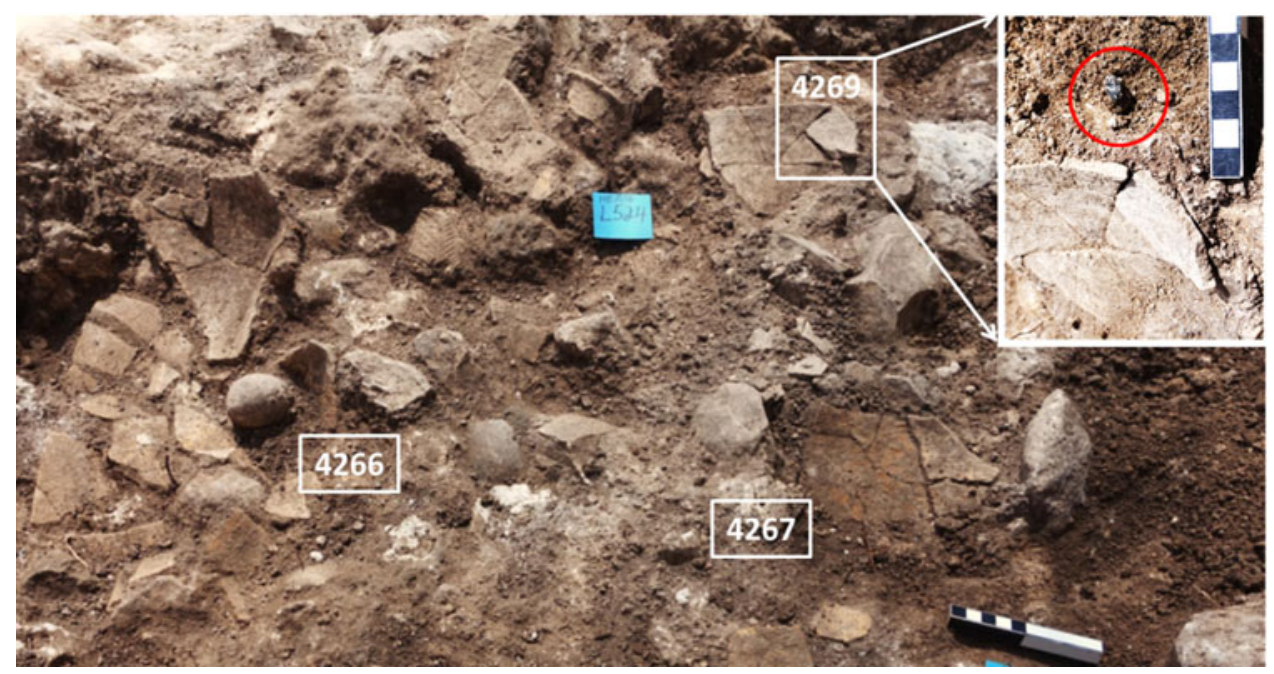

Figure 4 KANE. Part of locus 524 looking east. In-situ IBA jar fragments resting on a cobblestone surface. Locations of the three dated olive-pits are marked with their field numbers. Inset shows olive pit 4269 in-situ (circled). Scale bar at the lower right corner is $10 \mathrm{~cm}$ (photo: Ron Lev).

like Er-Rujum (Milevski et al. 2012), Jebel Qa'aqir (Gittin 1975), and Beit-Nehemia (Yekutieli et al. 2015). Yet, several features of KANE IBA pottery assemblage may reflect an earlier phase within the IBA pottery evolution when compared to the other above mentioned sites (Walzer et al. 2018). 


\section{MATERIALS AND METHODS}

Excavation of installation L524 was conducted carefully with small tools, removing 3 to 5-cm-thin layers of sediments at a time. The first stage was to expose the pottery level across the paved surface. The second stage was to excavate the pottery layer with the sediment in-between the pottery searching for datable organic samples. The excavated sediment was closely examined by eye in-situ, and then spread evenly over a clean flat tray, around $100 \mathrm{gr}$ at a time, in order to locate seeds and pits within the sediment. The identified charred remains were documented and collected in aluminum foil envelopes.

Sediment samples for FTIR (Fourier transform infrared spectroscopy) analysis were collected from various locations during the excavation, and from outside the archaeological site as a control. These samples were analyzed by FTIR for mineral composition and for the presence of anthropogenic features such as burnt clay and phosphates, using $\mathrm{KBr}$ pellets and a Nicolet iS5 FTIR (Berna et al. 2007; Weiner 2010).

Artifacts (ceramic, flint, stone) were collected and processed according to the overall site excavation routine. Phytoliths (plant siliceous remains) were counted within sediment samples that were collected inside and around L514/L524 installation to compare their presence within the various locations, using the phytolith extraction and quantification procedure (Katz et al. 2010).

Prior to ${ }^{14} \mathrm{C}$ analysis, all collected charred samples were botanically identified using a binocular microscope Leica M80. Three charred olive pits that were found in L524 between the IBA pottery sherds on-top of the stone surface were selected for ${ }^{14} \mathrm{C}$ dating (Figure 4). The samples were pretreated for removal of contaminants like carbonate and humic substances using the AAA (acid, alkaline, acid) protocol (Yizhaq et al. 2005; Rebollo et al. 2008). After the pretreatment, the charred material was tested with FTIR to verify the absence of clay and carbonate. Combustion and oxidation to $\mathrm{CO}_{2}$ were performed under vacuum at $900^{\circ} \mathrm{C}$ with $\mathrm{CuO}$. Once the $\mathrm{CO}_{2}$ was obtained, it was transformed into graphite and measured at the Dangoor REsearch Accelerator Mass Spectrometer (D-REAMS) at the Weizmann Institute of Science (Regev et al. 2017). ${ }^{14} \mathrm{C}$ ages are reported in conventional ${ }^{14} \mathrm{C}$ years $\mathrm{BP}$ (Before Present, where "present" is defined as year 1950) in accordance with international convention (Stuiver and Polach 1977). The ${ }^{14} \mathrm{C}$ ages were calibrated using the OxCal 4.3 online version (https://c14.arch.ox.ac.uk/oxcal/OxCal.html) and the IntCall3 calibration curve (Reimer et al. 2013).

\section{RESULTS}

Phytoliths (plants siliceous remains) were counted within the sediment samples that were collected inside and around L514/L524 installation (Figure 5). On average the sediment of the pottery layer inside the installation where the olive pits were collected contained over seven times more phytoliths counted per gram of sediment compared to the sediment around the installation.

The three single olive pits found in Locus 524 were pretreated for ${ }^{14} \mathrm{C}$ dating. The samples were in a good state of preservation as shown by the high efficiency (Eff \%) and by carbon percentage $(\mathrm{C} \%)$ around $70 \%$ in the clean material. The ${ }^{14} \mathrm{C}$ dates of the three olives pits in Locus 524 at KANE together with the calibrated ranges and the chemical details are given in Table 1. 
Table $1{ }^{14} \mathrm{C}$ dates and chemical pretreatment data of the 3 single olive pits from locus 524 at KANE.

\begin{tabular}{|c|c|c|c|c|c|c|}
\hline $\begin{array}{l}\text { Sample } \\
\text { number }\end{array}$ & $\begin{array}{l}\text { Field } \\
\text { ID }\end{array}$ & $\begin{array}{c}{ }^{14} \mathrm{C} \text { age } \pm 1 \sigma \\
\text { year BP }\end{array}$ & $\begin{array}{l}\text { Calibrated range } \\
\quad \pm 1 \sigma \mathrm{BC}\end{array}$ & $\begin{array}{l}\text { Calibrated range } \\
\quad \pm 2 \sigma \mathrm{BC}\end{array}$ & $\begin{array}{c}\text { Eff. } \\
\%\end{array}$ & $\begin{array}{l}\mathrm{C} \\
\%\end{array}$ \\
\hline RTD-8819 & B4267 & $3960 \pm 28$ & 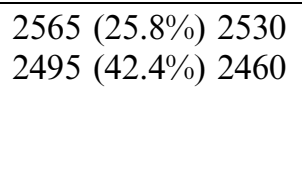 & $\begin{array}{c}2570(33.3 \%) 2515 \\
2505(50.0 \%) 2430 \\
2425(5.0 \%) 2400 \\
2380(7.1 \%) 2350\end{array}$ & 55.7 & 69.8 \\
\hline RTD-8820 & B4269 & $3967 \pm 26$ & 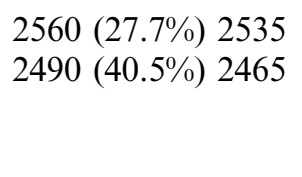 & 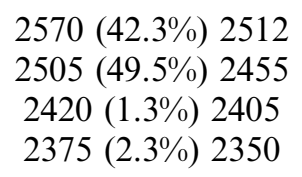 & 56.4 & 69.2 \\
\hline RTD-8785 & B4266 & $3999 \pm 35$ & $\begin{array}{l}2565(46.7 \%) 2520 \\
2500(21.5 \%) 2475\end{array}$ & $\begin{array}{c}2620(1.6 \%) 2605 \\
2600(0.7 \%) 2595 \\
2585(93.2 \%) 2460\end{array}$ & 62.6 & 70.7 \\
\hline \multicolumn{2}{|c|}{ Combine date } & $\begin{array}{c}3972 \pm 17 \\
2490(43.4 \%) \\
2470\end{array}$ & $\begin{array}{l}2560(24.8 \%) 2535 \\
2500(55.0 \%) 2465\end{array}$ & $2565(40.4 \%) 2525$ & NA & NA \\
\hline
\end{tabular}

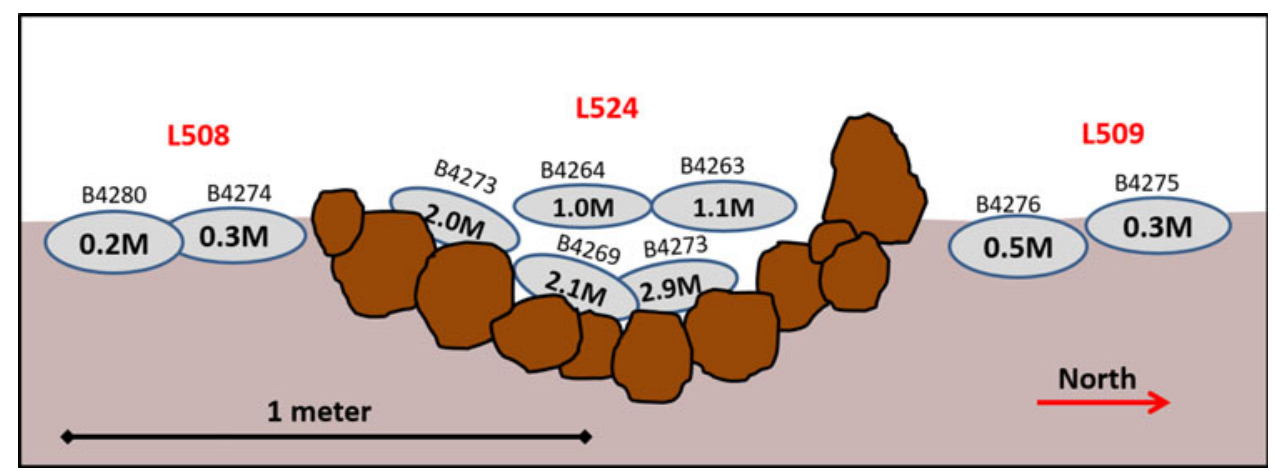

Figure 5 Schematic display of phytoliths count within $1 \mathrm{~g}$ of sediment (circled numbers) at various locations inside and adjacent to installation L514/L524.

\section{DISCUSSION}

The dated olive pits of KANE were collected from a cobblestone paved concave installation which included a 5-10-cm layer of in-situ IBA pottery fragments, lying just on-top of the installation bottom stones (Figure 4). The dated olive pits, along with a few other charred grains, were found between or right under the in-situ pottery shards. No charred remains were found in the layer right above the in-situ pottery of that locus, despite a careful search for such remains.

All pottery found inside installation L514 was clearly identified as from the IBA period. Pottery or material remains indicative of other periods were not found within the installation. The phytoliths that were counted inside and around installation L514 show that there are 


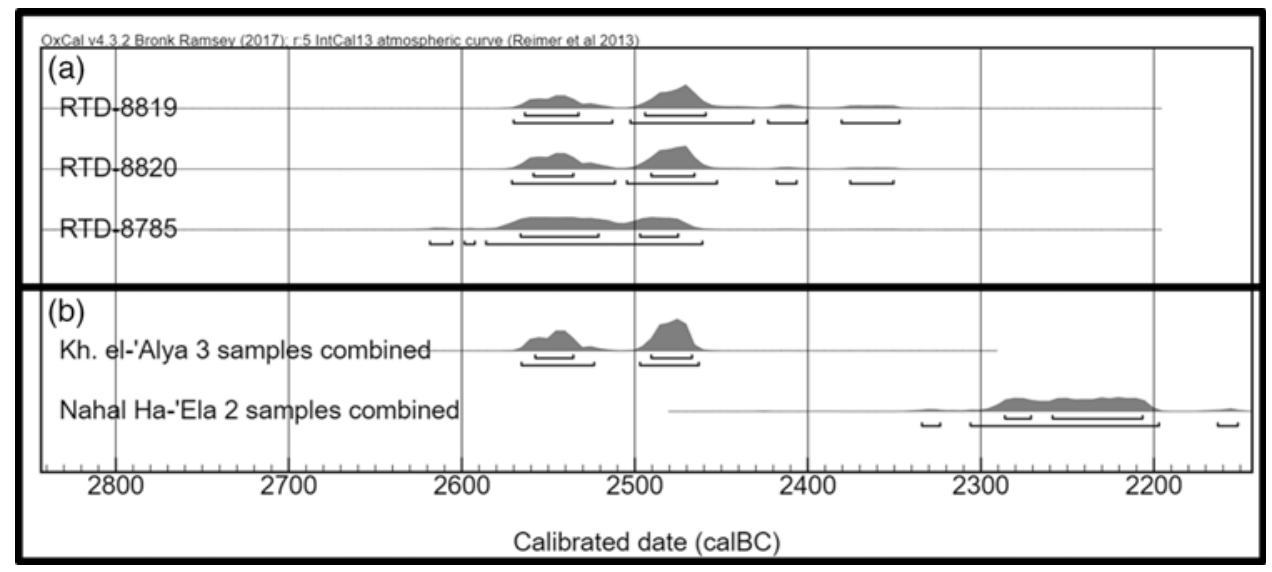

Figure 6 (a) Calibrated dates probability distribution of 3 olive pit samples from KANE. Samples are ordered from youngest to oldest. (b) Probability distribution of calibrated age of the average of the dated samples from Kh. el-'Alya compare to that of Nahal Ha-'Ela.

7 times more phytoliths in the sediment of the pottery layer inside the installation where the olive pits were collected, than in the sediment all around the installation (Figure 5). This shows that the sediment of the pottery layer inside the installation is significantly different from the sediment around the installation, and that there was no significant post depositional mixing between them. It is important to note that EB-III material remains were not found at this site during the excavation that reached bedrock and virgin soil in multiple locations. These olive pits could not originate from an earlier EBA occupation phase at the site. The few later-period remains found at this site are from the Iron age IIB, and cannot be associated with the olive pits which were dated millennia earlier.

The above observations present solid evidence that the 3 dated olive pits originated from a secure IBA context, and so their dates represent the time that installation L514 was in use within the IBA period (Figure 6). We note that this early date for an IBA context (2570 2460 BC 2- $\sigma$ calibrated date, see Table 1) was obtained from a few olive pits from the same context (one olive pit was processed in a separate preparation and was analyzed on a different dating run than the other two). This early date supports and complements the "high" absolute chronology for the EB-III period in the southern Levant (Regev et al. 2012b). For a different opinion see Nigro et al. (2019). The KANE IBA dates show that in this region, the IBA material culture appeared just after, or in parallel with the final decline of the previous EB-III urban culture, around 2500 BC.

Furthermore, KANE is situated less than $2 \mathrm{~km}$ north of the important EB-III fortified city of Tel Yarmuth (e.g. de Miroschedji 1999; see also Shalev and Golani 2018). ${ }^{14} \mathrm{C}$ dating research was done on Tel Yarmuth EB city, including a set of dates from the last stage of the city: EBIIIc (Regev et al. 2012a). The ${ }^{14} \mathrm{C}$ dates from Tel Yarmuth and from KANE were all obtained from charred botanic remains and were prepared in the same lab using the same protocol. This provides a good basis for modeling the ${ }^{14} \mathrm{C}$ dates from these two sites together, using the Bayesian method and the mathematical tools as given in OxCal v 4.3 (Bronk Ramsey 2009). Two alternatives were modeled. In the first (models $a, b)$ the Tel Yarmuth dates were defined as being older than the KANE samples, while in the second (models $\mathrm{c}$, d) no constraints between 
Table 2 Transition dates between Tel Yarmuth EB-IIIc level and KANE IBA level according to the different models. This table is built on the whole assemblage retrieved from KANE, not only Locus 524 shown in Figure 3.

Model type

Tel Yarmuth EB-IIIc - KANE IBA single boundary $(\mathrm{BC})$

\begin{tabular}{|c|c|c|c|c|}
\hline \multirow[t]{2}{*}{$\begin{array}{l}\text { Sequential phases, single boundary } \\
\text { Model a (Figure 7) } \\
\text { Model b (RT-2968 as outlier) }\end{array}$} & \multicolumn{2}{|c|}{$\begin{array}{c} \pm 1 \sigma \\
2570-2480\end{array}$} & $\begin{array}{r} \pm \\
2600 \\
2690\end{array}$ & $\begin{array}{l}\sigma \\
2470 \\
2480\end{array}$ \\
\hline & \multicolumn{2}{|c|}{$\begin{array}{l}\text { Tel Yarmuth EB-IIIc } \\
\text { end boundary (BC) }\end{array}$} & \multicolumn{2}{|c|}{$\begin{array}{c}\text { KANE IBA } \\
\text { start boundary (BC) }\end{array}$} \\
\hline Independent phases & $\pm 1 \sigma$ & $\pm 2 \sigma$ & $\pm 1 \sigma$ & $\pm 2 \sigma$ \\
\hline Model c (Figure 7) & $2570-2440$ & $2820-2300$ & $2590-2470$ & $2750-2470$ \\
\hline Model d (RT-2968 as outlier) & $2800-2570$ & $2850-2490$ & $2590-2470$ & $2750-2470$ \\
\hline
\end{tabular}

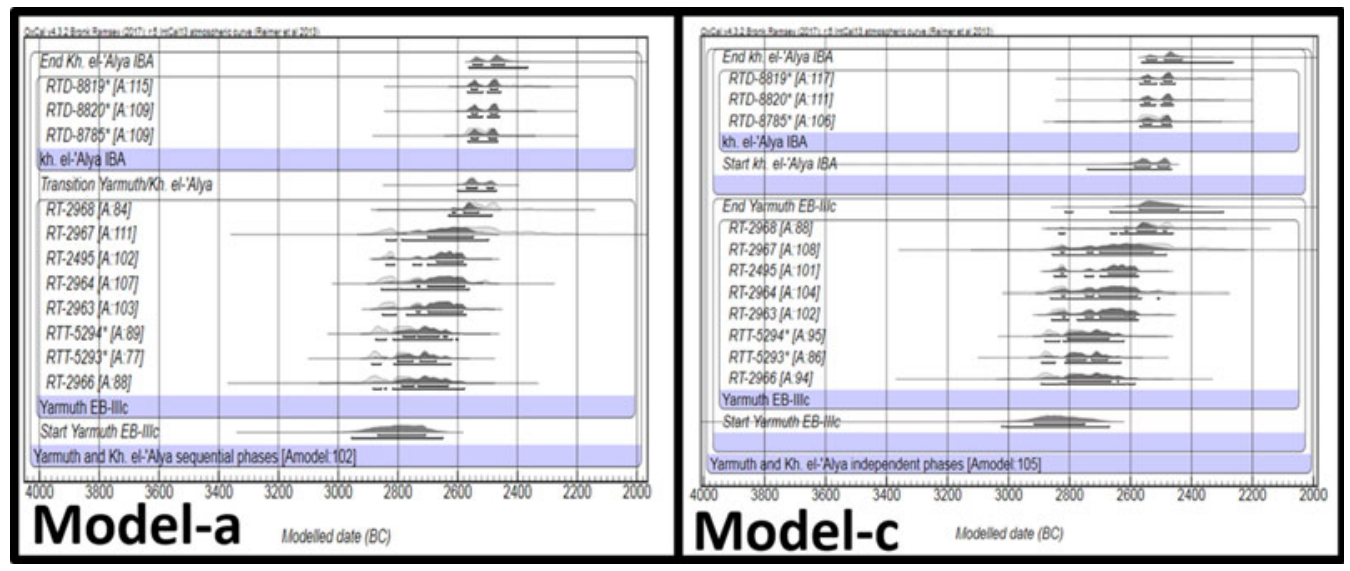

Figure 7 Model-a) Sequential probability distribution modeling where Tel Yarmuth phase EB-IIIc ${ }^{14} \mathrm{C}$ samples defined older than KANE IBA ${ }^{14} \mathrm{C}$ samples. Model-c) Sequential probability distribution modeling where there are no constrains between Tel Yarmuth phase EB-IIIc and KANE IBA ${ }^{14} \mathrm{C}$ samples, thus allowing overlap. Short-lived samples are marked with asterisks.

the two sites were defined, thus allowing overlap. One of Tel Yarmuth EB-IIIc level samples (RT-2968) gave a later date than seven other dates from the same level. In the Tel Yarmuth dating research, this sample was considered as a possible outlier in the EB-IIIc context, possibly representing secondary use of Tel Yarmuth ruins after its abandonment (Regev et al. 2012a: 523). Due to that fact two options regarding this sample RT-2968 were modeled here: as a valid Yarmuth EB-IIIc date (models a, c), and as an outlier (models b, d). Thus, four models are presented (Table 2, Figure 7). All Tel Yarmuth dates were taken from Regev et al. (2012a).

The modeling presented in Table 2 shows that in all cases there was no apparent chronological gap between the end of the Tel Yarmuth EB-III city, and the appearance of IBA culture in 
KANE. Models a and $\mathrm{c}$ set the transition between the sites around the second half of the 26th century BC, while models b and d (considering RT-2968 as an outlier) set the transition between the sites around the first half of the 26th century BC. Model c displays a probable period of coexistence of the two sites, thus presenting the possibility that the occupation of KANE started even before the abandonment of Tel Yarmuth.

It was noted that the predecessors of the IBA pottery repertoire in general may be in the EB-III pottery tradition (e.g. Richard 1980). When the EB-IIIc pottery of Tel Yarmuth is compared with the limited pottery assemblage from KANE, the differences are quite noticeable as can be seen in Table 3 (for a comprehensive analysis of IBA pottery see D'Andrea 2014).

Recent research, conducted as part of the Ramat Bet-Shemesh Regional survey, enables us to compare settlement patterns in the vicinity of KANE during the EB-III and IBA. According to this survey there is a concentration of IBA sites within a few kilometers distance from KANE. This presents a different site distribution pattern than EB-III sites that were identified in the same survey (Figure 8; Dagan 2011: 242-248). It can also be noted that the location of all IBA sites identified to date in this area had Tel Yarmouth hidden from their eyesight (Walzer et al. 2018: 185). When combining the above observations of no chronological gap between EB-IIIc Tel Yarmuth and KANE (Table 2) with the considerably different material culture (Table 3), and with the different site distribution patterns (Figure 8), it may be suggested that the people that have settled in KANE had a different and already developed material culture and were not previous inhabitants of Tel Yarmuth. Another possibility is that the inhabitants of KANE, and perhaps of other IBA settlements at Ramat Bet-Shemesh, had deliberately left Tel Yarmouth and quit urban life, thus replacing one ideological system with another (Bunimovitz and Greenberg 2004). Such a process may have its roots already during the last days of the city at Tel Yarmouth, as "refugees" from a collapsing city system sought a different livelihood (Greenberg 2017).

An additional IBA site, Nahal Ha-'Ela, located less than $4 \mathrm{~km}$ south of KANE (Figure 8) was also excavated recently. Nahal Ha-'Ela site is a small settlement including a house and adjacent installations ( $\mathrm{Paz}$ 2016). Olive pits were found inside dark patches at the bottom of a stone-built installation (Locus 135) within a clear IBA context. The two olive fragments dated provided a calibrated date range within the 23rd century BC (Table 4), about 200 years later than the dates of KANE, yet still well inside the IBA timeframe (Figure 6).

The concentration of multiple IBA small single level sites directly on top of bedrock, all within a small geographical area (Figure 8) and with chronological differences (at least between two of these sites), points to a possible settlement pattern of establishing a new site on virgin ground/ bedrock, living there for some time, followed by abandonment and establishment of a new one not far away, on an unexploited patch of land. This interpretation may explain why most IBA sites seem to be ephemeral settlements, even though the IBA period, as a whole, extended for over half a millennium.

\section{CONCLUSIONS}

The early IBA dates from KANE in Israel presented above, as well as similar early ${ }^{14} \mathrm{C}$ dating results of IBA context from Trans-Jordan at Tell Abu en-Ni'aj, support setting the end of the EB-III culture to around $2500 \mathrm{BC}$. These dates suggest that IBA material culture appeared in 
Table 3 Comparison between the pottery assemblages of the EB-IIIc at Tel Yarmuth and the Early IBA at KANE.

\begin{tabular}{|c|c|c|}
\hline \multicolumn{3}{|c|}{ Typological continuity and changes } \\
\hline Feature & EB-IIIc Tel Yarmuth (de Miroschedji 2000) & Early IBA KANE (this work) \\
\hline "Caliciform" cups & No cups & Low frequency of cups \\
\hline Platters & Large variety of platters & No platters \\
\hline Profiled-rim bowls & $\begin{array}{l}\text { Rim folded on the interior; red burnished slip on } \\
\text { interior; whitewash on the exterior }\end{array}$ & $\begin{array}{l}\text { Rim folded on the interior; no red burnished, no whitewash; } \\
\text { rope-like decoration on rim exterior }\end{array}$ \\
\hline Storage jars & $\begin{array}{l}\text { Simple flaring rim; short neck; wheel-combing and } \\
\text { whitewash }\end{array}$ & Simple flaring rim; high neck; handmade, no whitewash \\
\hline Ledge handles & Wavy & Pinched or semi-folded \\
\hline Holemouth & $\begin{array}{l}\text { Rounded or bulbus rim; decoration: wheel-combing } \\
\text { and sometimes whitewash }\end{array}$ & $\begin{array}{l}\text { Geometric rim, square or triangular profile; decoration: } \\
\text { incision with a single point or gentle rope-like below the } \\
\text { rim }\end{array}$ \\
\hline Spouted vessels & Spouted vats & Spouted holemouth \\
\hline Pithoi & $\begin{array}{l}\text { Outer-folded rim; rope-like decoration; combing } \\
\text { and whitewash; potter's mark }\end{array}$ & Simple flaring rim; rope-like decoration \\
\hline Ware & Homogeneity; brown-red coarse ware & Variety \\
\hline Surface treatment & $\begin{array}{l}\text { Wheel-combed and whitewash on many kinds of } \\
\text { vessels; red burnishing on bowls, platters and jugs }\end{array}$ & $\begin{array}{l}\text { Incised decoration made with a single point on holemouths; } \\
\text { band-combing on cups; no burnishing, no whitewash }\end{array}$ \\
\hline Manufacturing & $\begin{array}{l}\text { Handmade wheel finished; wheel turned; } \\
\text { standardization; single workshop }\end{array}$ & Handmade \\
\hline
\end{tabular}




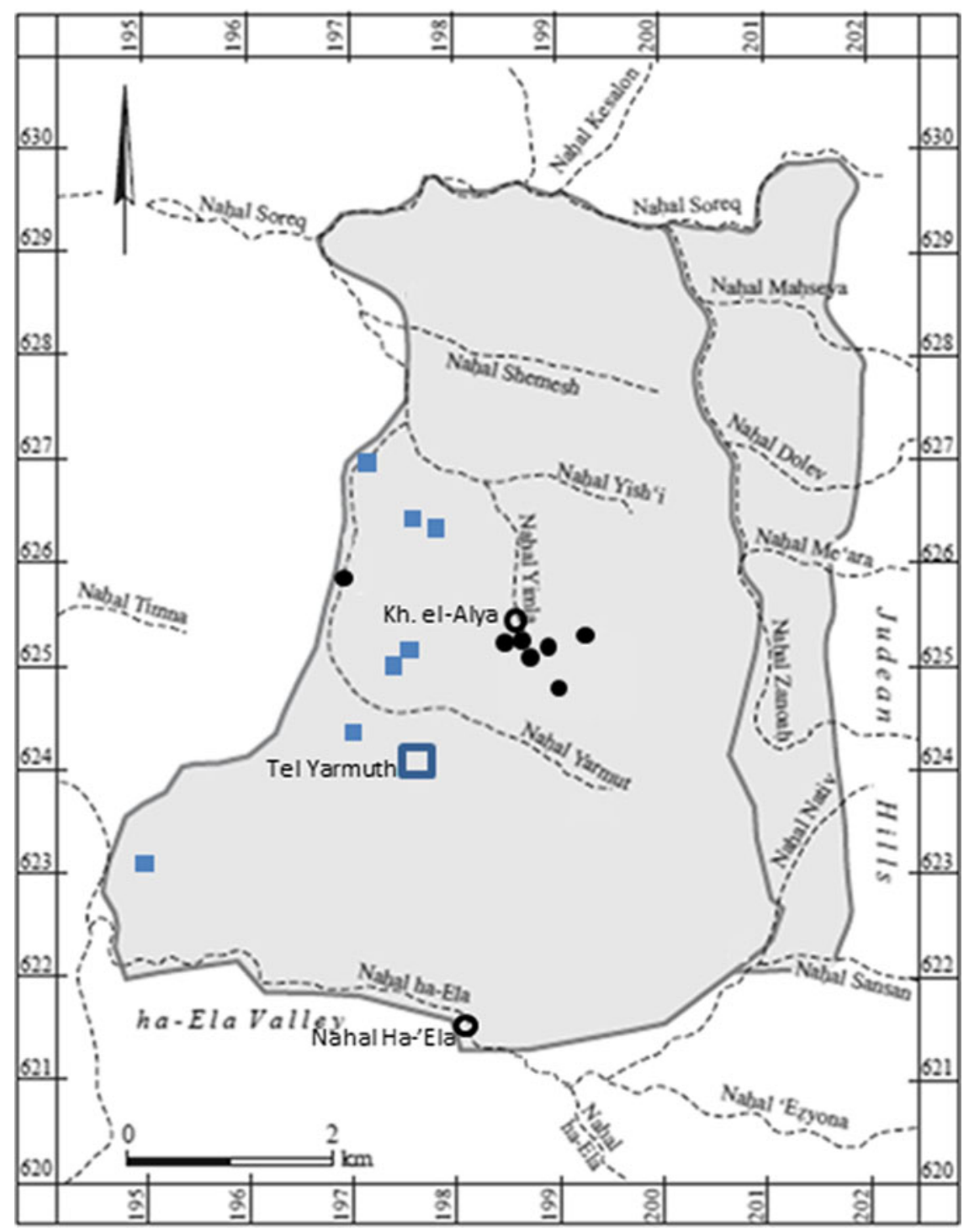

Figure 8 Map displaying EB-III sites with architectural remains (marked by squares) and IBA sites with architectural remains (marked by circles) that were identified in the Ramat Bet-Shemesh Regional Project survey (map and sites location adapted from Dagan 2011: Figs. 4.14, 4.15). KANE and Nahal Ha-'Ela sites were identified and excavated after the survey's completion and were added on top of the survey results.

the southern Levant in very close timing to the decline of the preceding EB-III urban culture: around $2500 \mathrm{BC}$, or somewhat earlier.

The distinct difference in the material culture between the last level of Tel Yarmuth EB-IIIc and the nearby IBA KANE, with no apparent chronological gap between them, suggests that KANE inhabitants settled near Tel Yarmuth with an already distinct and developed material culture. An alternative explanation presented above considers the possibility that the IBA KANE settlement was initiated by Tel Yarmuth people. 
Table $4{ }^{14} \mathrm{C}$ dating results of 2 olive pit samples from Nahal Ha-'Ela Site.

\begin{tabular}{|c|c|c|c|c|c|c|}
\hline $\begin{array}{l}\text { Sample } \\
\text { no. }\end{array}$ & $\begin{array}{l}\text { Field } \\
\text { ID }\end{array}$ & Locus & $\begin{array}{c}{ }^{14} \mathrm{C} \text { age } \pm 1 \sigma \\
\text { year } \mathrm{BP}\end{array}$ & $\begin{array}{l}\text { Calibrated range } \\
\quad \pm 1 \sigma \mathrm{BC}\end{array}$ & $\begin{array}{l}\text { Calibrated range } \\
\quad \pm 2 \sigma \mathrm{BC}\end{array}$ & $\begin{array}{l}\text { AMS } \\
\delta^{13} \mathrm{C}\end{array}$ \\
\hline $\begin{array}{r}\text { RTD- } \\
4796\end{array}$ & B1118 & L. 135 & $3789 \pm 26$ & 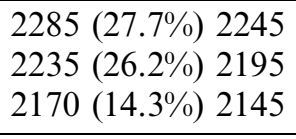 & $2295(95.4 \%) 2140$ & -21.74 \\
\hline $\begin{array}{r}\text { RTD- } \\
4797\end{array}$ & B1119 & L. 135 & $3838 \pm 27$ & 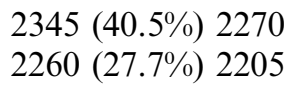 & $\begin{array}{l}2460(6.5 \%) 2415 \\
2410(88.8 \%) 2200\end{array}$ & -21.17 \\
\hline Combine & & & $3813 \pm 19$ & $\begin{array}{l}2290(15.1 \%) 2270 \\
2260(53.1 \%) 2205\end{array}$ & $\begin{array}{l}2335(1.5 \%) 2320 \\
2310(92.0 \%) 2195 \\
2165(1.9 \%) 2150\end{array}$ & \\
\hline
\end{tabular}

The many small single occupation IBA sites discovered in the vicinity of KANE, including one dated 200 years later (et Nahal Ha-'Ela), indicate that the IBA settlement pattern, at least in this area, might have been a relatively short occupation and then they moved into an unexploited location nearby.

\section{REFERENCES}

Amiran R. 1970. Ancient pottery of the Holy Land: from its beginnings in the neolithic period to the end of the iron age. New Brunswick: Rutgers University Press.

Bar S, Cohen O, Zertal A. 2013. New aspects of the intermediate Bronze Age (IB/MBI/EBIV): Khirbet el-meiyiteh-A fortified site on the eastern fringe of samaria. Revue Biblique (2):161-181.

Berna F, Behar A, Shahack-Gross R, Berg J, Boaretto E, Gilboa A, Sharon I, Shalev S, Shilstein S, Yahalom-Mack N, Zorn JR, Weiner S. 2007. Sediments exposed to high temperatures: reconstructing pyrotechnological processes in Late Bronze and Iron Age Strata at Tel Dor (Israel). Journal of Archaeological Science 34(3):358-373.

Bronk Ramsey C. 2009. Bayesian analysis of radiocarbon dates. Radiocarbon 51(1):337-360.

Bunimovitz S, Greenberg R. 2004. Revealed in their cups: Syrian drinking customs in Intermediate Bronze Age Canaan. Bulletin of the American Schools of Oriental Research (334):19-31.

D'Andrea M. 2012. The Early Bronze IV period in south-central Transjordan: reconsidering chronology through ceramic technology. Levant 44(1):17-50.

D'Andrea M. 2014. The Southern Levant in Early Bronze IV: issues and perspectives in the pottery evidence. Roma: Sapienza - Universita di Roma.

Dagan Y. 2011. Patterns of settlement: Chalcolithic to Ottoman periods. In: Dagan Y, editor. The Ramat Bet Shemesh Regional Project: landscapes of settlement from the Paleolithic to the Ottoman periods, 231-296. Israel Antiquities Authority.

Dever WG. 1980. New vistas on the EB IV ('MB I') Horizon in Syria-Palestine. Bulletin of the American Schools of Oriental Research 237:35-64.

Dever WG. 2014. Excavations at the Early Bronze IV Sites of Jebel Qa'aqir and Be'er Resisim. Winona Lake.

Dunseth ZC, Junge A, Lomax J, Boaretto E, Finkelstein I, Fuchs M, Shahack-Gross R. 2017. Dating archaeological sites in an arid environment: A multi-method case study in the Negev Highlands, Israel. Journal of Arid Environments 144:156-169.

Falconer SE, Fall PL. 2016. A radiocarbon sequence from Tell Abu en-Ni‘Aj, Jordan and its implications for Early Bronze IV chronology in the southern Levant. Radiocarbon 58(3):615-647.

Falconer SE, Fall PL. 2019. Early Bronze IV Village lfe in the Jordan Valley-excavations at Tell Abu en-Ni'aj and Dhahret Umm el-Marar, Jordan. BAR Publishing.

Feig N. 2016. Khirbat er-Ras, Jerusalem: Iron Age and Ottoman-period remains. Hadashot Arkheologiyot 128.

Fraser J. 2017. Khirbet Um al-Ghozlan. In: Archaeology in Jordan Newsletter: 2016 and 2017 Seasons: 27-28. Amman: ACOR.

Gittin S. 1975. Middle Bronze I "Domestic" Pottery at Jebel Qa'aqir : a ceramic inventory of Cave G 23. Israel Exploration Society.

Greenberg R. 2017. No collapse: transmutations of Early Bronze Age urbanism in the Southern 
Levant. In: Hoflmayer F, editor. The late third millennium in the ancient Near East: chronology, C14, and climate change. Chicago: The University of Chicago Oriental Institute Seminars. p. 33-60.

Höflmayer F, Dee MW, Genz H, Riehl S. 2014. Radiocarbon evidence for the Early Bronze Age Levant: the site of Tell Fadous-Kfarabida (Lebanon) and the end of the Early Bronze III period. Radiocarbon 56(2):529-542.

Katz O, Cabanes D, Weiner S, Maeir AM, Boaretto E, Shahack-Gross R. 2010. Rapid phytolith extraction for analysis of phytolith concentrations and assemblages during an excavation: An application at Tell es-Safi/Gath, Israel. Journal of Archaeological Science 37(7): 1557-1563.

Kennedy MA. 2016. The end of the 3rd millennium $\mathrm{BC}$ in the Levant: new perspectives and old ideas. Levant 48(1):1-32.

Mazar A. 1990. Archaeology of the land of the Bible: 10,000-586 B.C.E. Yale University Press.

Milevski I, Cohen-Weinberger A, Boaretto E, Kamaisky E, Khalaily H, Liphschitz N, Moshe S, Shalev S. 2012. Er-Rujum (Sha'alabim East): an intermediate Bronze Age (EB IV) site in the Ayyalon Valley. Atiqot 69:75-140. Israel Antiquities Athority.

de Miroschedji P. 1999. Yarmuth: the dawn of city-states in southern Canaan. Near Eastern Archaeology 62(1):2-19.

de Miroschedji P. 2000. An Early Bronze Age III Pottery sequence for southen Israel. In: Philip $\mathrm{G}$, Baired D, editors. Ceramics and change in the Early Bronze Age of the Southen Levant. Sheffield Academic Press. p. 315-345.

de Miroschedji P. 2009. Rise and collapse in the Southern Levant in the Early Bronze Age. In Scienze dell'antichità. Roma: Universita Degli Studi di Roma - La Sapienza. Storia Archeologia Antropologia 15:101-129.

Nigro L, Calcagnile L, Yasin J, Gallo E, Quarta G. 2019. Jericho and the chronology of Palestine in the early Bronze Age: a radiometric re-assessment. Radiocarbon 61(1):211-241.

Paz Y. 2016. Nahal Ha-'Ela. Hadashot Arkheologiyot 128.

Rebollo NR, Cohen-Ofri I, Popovitz-Biro R, Bar-Yosef O, Meignen L, Goldberg P, Weiner S, Boaretto E. 2008. Structural characterization of charcoal exposed to high and low $\mathrm{pH}$ : implications for ${ }^{14} \mathrm{C}$ sample preparation and charcoal preservation. Radiocarbon 50(2): 289-307.

Regev J, de Miroschedji P, Boaretto E. 2012a. Early Bronze Age chronology: radiocarbon dates and chronological models from Tel Yarmuth (Israel). Radiocarbon 54(3-4):505-524.

Regev J, de Miroschedji P, Greenberg R, Braun E, Greenhut Z, Boaretto E. 2012b. Chronology of the Early Bronze Age in Southern Levant: new analysis for a high chronology. Radiocarbon 54(3-4):525-566.

Regev J, Finkelstein I, Adams MJ, Boaretto E. 2014. Wiggle-matched ${ }^{14} \mathrm{C}$ chronology of Early Bronze Megiddo and the synchronization of Egyptian and Levantine chronologies. Agypten und Levante 24:243-266.

Regev L, Steier P, Shachar Y, Mintz E, Wild EM, Kutschera W, Boaretto E. 2017. D-REAMS: a new compact AMS system for radiocarbon measurements at the Weizmann Institute of Science, Rehovot, Israel. Radiocarbon 59(3): 775-784.

Reimer PJ, Bard E, Bayliss A, Beck JW, Blackwell PG, Bronk Ramsey C, Grootes PM, Guilderson TP, Haflidason H, Hajdas I, Hatt C, Heaton TJ, Hoffmann DL, Hogg AG, Hughen KA, Kaiser KF, Kromer B, Manning SW, Niu M, Reimer RW, Richards DA, Scott EM, Southon JR, Staff RA, Turney CSM, van der Plicht J. 2013. IntCal13 and Marine13 radiocarbon age calibration curves $0-50,000$ years cal BP. Radiocarbon 55(4):1869-1887.

Richard S. 1980. Toward a consensus of opinion on the end of the Early Bronze Age in PalestineTransjordan. Bulletin of the American Schools of Oriental Research 237: 5-34.

Richard S. 2010. Khirbet Iskander: final report on the Early Bronze IV Area C "Gateway" and cemeteries. Boston (MA): American Schools of Oriental Research.

Segal D, Carmi I. 2004. Rehovot radiocarbon date list VI. Israel Antiquities Authority. Atiqot 48:123-148.

Shalev O, Dallashah S. 2017. Khirbat el-'Alya. Hadashot Arkheologiyot 129.

Shalev O, Golani A. 2018. Tel Yarmut. Hadashot Arkheologiyot 130.

Stuiver M, Polach HA. 1977. Reporting of ${ }^{14} \mathrm{C}$ data: discussion. Radiocarbon 19(3):355-363.

Vogel JC, Visser E, Fuls A. 2001. Suitability of ostrich eggshell for radiocarbon dating. Radiocarbon 43(1):133-137.

Walzer N, Shalev O, Paz Y. 2018. From city to village: the transition from the Early Bronze Age III to the Intermediate Bronze Age in the Judean Shephelah, a view from Ramat Bet Shemesh. New Studies in the Archaeology of Jerusalem and its Region 12:171-190. In Hebrew.

Weiner S. 2010. Microarchaeology-beyond the visible archaeological record. Cambridge University Press.

Yannai E. 2014. Tel Zivda. Hadashot Arkheologiyot 126:1-13.

Yekutieli Y, Paran N-S, Ben-Yishai Y. 2015. Bet Nehemya. Hadashot Arkheologiyot 127:5-9.

Yizhaq M, Mintz G, Cohen I, Khalaily H, Weiner S. 2005. Quality controlled radiocarbon dating of bones and charcoal. Radiocarbon 47(2):193-206. 